\title{
A Journey up the Machili
}

\section{Author(s): Percy C. Reid}

Source: The Geographical Journal, Vol. 9, No. 2 (Feb., 1897), pp. 143-145

Published by: geographicalj

Stable URL: http://www.jstor.org/stable/1773500

Accessed: 21-06-2016 10:09 UTC

\section{Your use of the JSTOR archive indicates your acceptance of the Terms \& Conditions of Use, available at}

http://about.jstor.org/terms

JSTOR is a not-for-profit service that helps scholars, researchers, and students discover, use, and build upon a wide range of content in a trusted digital archive. We use information technology and tools to increase productivity and facilitate new forms of scholarship. For more information about JSTOR, please contact support@jstor.org.

The Royal Geographical Society (with the Institute of British Geographers), Wiley are collaborating with JSTOR to digitize, preserve and extend access to The Geographical Journal 
I will simply give a few distinguishing characteristics relative to the tribes I travelled among. Their tribal distribution is to be found on my map. In colour they are all-with perhaps the exception of the Mashikolumbwe - much blacker than the South African. Almost throughout I noticed an inferior type of native, varying little in different districts, who have probably much common blood derived from an aboriginal race occupying the country prior to the Bantu incursion. These people I exclude from the following remarks.

The Marotse are the ruling tribe. Each Barotse is a chief by birth. Their physique is good; manner dignified and courteous, though they have not learnt the art of telling the truth-a general failing among their neighbours. They are very clever at wood-carving, considering the crudeness of their tools.

The Mabunda, a shorter but thick-set race, are very clever in the art of basket and mat making.

Among the Matutela, I was struck by the number of tall slight men, with good features and long pointed beards. They are the iron-workers of the empire, and supply their neighbours with assegais, axes, knives, etc. They also almost monopolize the canoe-building industry.

The Masubia, many of whom are of magnificent physique, supply most of the paddlers on the Zambezi. They are a hunting people.

The Mxtoka are men of good physique, make good porters, and cultivate cereals largely.

The Mankoya are a race of hunters, are shorter than their neighbours, and, though generally supposed to be inferior, I must confess I was agreeably surprised with them. They use poisoned arrows, which are also carried by every Mashikolumbwe warrior. The physique of the Mashikolumbwe is, so far as I was able to judge from six weeks' contact with them, their only good quality. They are a treacherous, indolent people, too lazy even to hunt. The cone on the back of their head distinguishes them from all other tribes. They also knock out the four upper central teeth and the back lower ones, giving themselves an ugly undershot appearance. This latter disfigurement is also resorted to by the Matoka, though by none of the other tribes, except the Matutela and a few Mankoya on their borders. The Marotse file their two front upper teeth, so as to form a reversed V.

\section{A JOURNEY UP THE MACHILI.}

\section{By PERCY C. REID.}

THE road from Mafeking through Palapye, the residence of Khama, the chief of the Bechuanas, to Kazungula at the junction of the Zambesi and the Linyanti (or Chobe) river, has already been frequently described, and I will therefore say nothing about it, but commence with Kazungula as our starting-point. Kazungula is an ordinary African village of the usual type, composed of circular huts built 
of mud and wattle, with thatched roofs. It is a village of quite recent construction, being only some six years old. Formerly the nearest village was at Mbofa, some 8 miles up the Zambesi, which, when I visited the country last in 1888, was under the charge of a headman named Makumba. Since then, however, contact with Europeans has largely increased, and a mission station was founded at Kazungula, with the result that the place became sufficiently important to induce Litia, the son of the chief Lewanika, to take up his residence there, and to remove bis subjects from Mbofa to the new location.

Starting from Kazungula on July 2 of last year, Captain Bertrand and I set out with the object of combining sport with a rough survey of the Machili river, which flows into the Kasaia, and thence into the Zambesi a short distance south of Sesheké. It took us three days to reach the Kasaia river, our march being sadly delayed by want of carriers and by unbroken donkeys. Our route so far had led along a well-beaten path and the waggon-track of the missionaries, leading to Sesheké and away on to Lialui, the capital. After crossing the Kasaia, however, we soon struck the Machili, and were then in unsurveyed country.

And here perhaps I may break the narrative of our journey, and, taking you at once to what we afterwards found to be the source of the river, may describe it from thence downwards, as this will render what $I$ have to say clearer and more interesting. The Machili rises on the southern slope of a high sand-ridge, at an altitude of about 3900 feet above sea-level. There is no absolute source, such as a bubbling spring, but merely a slight ill-defined valley about 100 yards wide, carpeted with grass and edged on both sides with forest. As one follows down the valley, it is joined by other small valleys similar, but smaller, and chiefly on the east bank, and at the junction of these with the main bed the ground becomes wet and oozy. The descent is fairly rapid, say 50 feet in a couple of miles, and then comes a slight outcrop of stones, and the first real water is found in a few rocky pools in the river's bed. The course is north-east to south-west, and in a few miles the sides of the valley have become steeper and the river full of water, in which a current is plainly visible. Some 5 miles down a considerable stream joins the Machili from the east, and a large pool is formed at the juncture, and below this the river is flowing strongly. Following the same general direction lat. $16^{\circ} 21^{\prime}$ is reached, and there, after emerging from stony ground, the valley opens out to a width of some 150 yards, and the river itself gradually dries up, and is soon quite lost, except for one or two stagnant pools in its bed. Some few miles lower the country on either side becomes again stony, and the river at once reappears, and, gaining volume, is soon running rapidly and noisily forward, in many places like a Scotch burn. About lat. $16^{\circ} 35^{\prime}$ it makes a sudden and sharp bend to the east, and, after flowing some 6 or 8 miles in this direction, emerges from the stony hills on to a wide " turf" valley (with an altitude of about 3400 feet), where it again suddenly bends to the south and becomes apparently stagnant, and in places almost dry. Another and similar but smaller bend to the east and then south occurs in lat. $16^{\circ} 48^{\prime}$, the valley again contracting and a certain flow of water becoming perceptible. From this point onwards for some 45 miles the same characteristics prevail, and then again the river becomes a series of deep pools with dry spaces in between. Here the river has become sufficiently large for the pools to contain hippopotami. The country now has become flatter, the valley of the river has disappeared, and the river continues in alternate pools and dry spaces until some 5 or 6 miles before the Kasaia is reached, when the pools of water cease entirely, and the river-bed itself also vanishes utterly. Of course, I am speaking now of the dry season. In the rains the river is full of water and flowing throughout; but the curious fact 
remains that when I saw it, it,was alternately flowing and stagnant, and that even in the wet season it empties itself into a large marsh, which in its turn drains rather than flows into the Kasaia. Wherever the subsoil is rocky and the fall somewhat pronounced, there we find water running throughout the year; where the country becomes more level and the soil alluvial turf (it is nowhere sandy), there the river is represented by pools, or loses itself entirely.

Viewing the river from its mouth upwards, the rise is very slight until you reach lat. $16^{\circ} 35^{\prime}$, when you first get really out of the Zambesi valley and into stony hills. Rising through these, you find beyond them a main high sandy ridge, which forms the watershed between the Kafukwe river and the Zambesi: This ridge runs approximately north-west to south-east, and is the origin of all the rivers flowing into the left bank of the Zambesi between Kazungula and the capital Lialui.

Vegetation throughout the country traversed is thick. In the alluvial parts it consists of high forest trees without much undergrowth; in the more stony and barren parts the forest is smaller and the undergrowth thicker-in places almost impenetrable jungle. Temperature in the winter months is very pleasant-about $80^{\circ}$ to $85^{\circ}$ in the shade at midday, and with cool refreshing nights. We experienced a sharp frost on July 31 at the source of the river, in lat. $16^{\circ} 9^{\prime}$. Population is sparse, but it is hard to judge population in Africa, as the villages are hidden away in the bush, and the natives rarely show themselves. Several tribes that go to form the Barotse nation inhabit the district. They cultivate several sorts of cereals and pulses, as well as tobacco, pumpkins, and several sorts of roots. They are clothed, if at all, in skins, and use skins to cover themselves at night. They are all armed with assegais, a very few have guns, still fewer have ammunition, and one tribe, the Mankojas, all carry bows and poisoned arrows. They are nearly all adepts at trapping game, either in pitfalls or snares. They are quite peaceably disposed, shy by nature, but soon become used to the presence of white men. They are indifferent carriers, and desert on slight provocation; but they rarely steal their loads, although they abandon them by the road. They are destitute of pluck, and would be of no use in a time of danger.

The game of the country is, or was, very numerous. I say "was," because I am sorry to hear that the rinderpest has devastated Barotseland as it has Matabeleland and Mashonaland, and that the game now is practically extinct, the carcases lying rotting in all directions. Elephant are very scarce-I did not see one; rhinoceros scarcer still; hippopotami are found in the Zambesi and Machili; while all over the country were buffalo, Burchell's zebra, many sorts of antelope, and many lions. Neither giraffe nor ostrich are found east of the Zambesi.

I thank you for the kindness with which you have listened to me, and if, as I hope, I may some day be able again to visit this part of the world, I will endeavour to bring back a larger and more valuable store of information on its geography and ethnography.

\section{FROM THE MACHILI TO LIALUI.}

\section{By Captain ALFRED BERTRAND.}

After the exploration of the Machili, in which I accompanied Mr. Reid, I determined to traverse the Barotse country in a nortb-westerly direction to Lialui, the residence of King Lewanika.

Taking with me twenty-five men and (as interpreter) an old half-caste elephant- 